\title{
PRICE EARNINGS RATIO DAN PENDAPATAN SAHAM PERUSAHAAN NON KEUANGAN DI BEI
}

\author{
I Made Sudana \& Hilda Putri Maulidiyah \\ Departemen Manajemen, Fakultas Ekonomi dan Bisnis, Universitas Airlangga \\ E-mail: imadesudana@yahoo.co.id \& xeroxzevana@gmail.com
}

\begin{abstract}
ABSTRAK
Penelitian ini bertujuan untuk menguji rasio antara PER, PEG, dan PERG yang dapat memprediksi return saham perusahaan dengan lebih baik dan menganalisis pengaruh masing-masing rasio terhadap return saham. Sampel penelitian terdiri dari 310 perusahaan non-keuangan di BEl selama periode 2010-2016. Pada penelitian ini, metode regresi linier berganda telah dilakukan untuk menjelaskan pengaruh PER, PEG, dan PERG dengan variabel kontrol SIZE, M / B , FLEV, dan pengembalian saham DPRon. Hasil penelitian menunjukkan bahwa PERG dapat menjelaskan pengembalian saham lebih baik daripada PER dan PEG berdasarkan nilai R-square yang lebih tinggi. Penelitian ini menggunakan tingkat signifikansi $5 \%, M / B$ dan FLEV yang memiliki pengaruh signifikan, sementara PER, PEG, dan PERG tidak berpengaruh signifikan terhadap return saham. Penelitian ini juga menunjukkan efek negatif PER, PEG, PERG, SIZE, FLEV, dan DPR serta efek positif M/B terhadap return saham.
\end{abstract}

Kata kunci: Return saham, PER, PEG, PERG.

\begin{abstract}
This research aims to examine which ratio between PER, PEG, and PERG that can better predict the stock returns of the firms, in addition to analyze the effect of each that ratio on stock return. The research sample consist of 310 non-financial firms in IDX during the period of 2010-2016.In this study, multiple linear regression methods have been conducted to explain the effect of PER, PEG, and PERG with control variable SIZE, M/B, FLEV, and DPRon stock return. The results indicate that PERG can explain stock returns better than PER and PEG based on the higher value of R-square. Using $5 \%$ level of significance, M/B and FLEV had a significant effect, while PER, PEG, and PERG had no significant effect on stock return. The study also showed a negative effect PER, PEG, PERG, SIZE, FLEV, and DPR as well as the positive effect of $M / B$ on stock returns.
\end{abstract}

Keywords: Stock returns, PER, PEG, PERG. 


\section{Made Sudana \\ Hilda Putri Maulidiyah}

\section{PENDAHULUAN}

Saham adalah tanda penyertaan modal pada suatu perusahaan dan merupakan surat bukti kepemilikan atas sebuah perusahaan. Pendapatan tahunan saham berupa capital gain sepanjang tahun 2008 hingga 2013 mencapai nilai tertinggi sebesar 76,32\% dan nilai terendah sebesar $-50,38 \%$ dengan rata-rata pendapatan sebesar 11,36\%. Nilai tersebut menunjukkan bahwa investor menghadapi risiko yang sangat tinggi, sehingga pengukuran kelayakan investasi perlu dilakukan oleh investor sebelum memutuskan untuk membeli saham.

Bagi investor, pendapatan merupakan tujuan utama dari investasi saham, sehingga mengukur besaran pendapatan yang mungkin diterima di masa yang akan datang menjadi aspek yang sangat penting bagi investor saham. Pengukuran dengan menggunakan model berbasis pendapatan berupa price earnings ratio (PER) merupakan model pengukuran yang paling sederhana. Meski demikian, penggunaan PER membuat investor sulit mengetahui apakah benar suatu saham dengan nilai PER tertentu memiliki pertumbuhan pendapatan yang sesuai dengan harapan. Hal ini menyebabkan PER tidak bisa dijadikan sebagai satusatunya acuan pendapatan saham di masa depan.

Ketika kelayakan PER sebagai prediktor pendapatan saham mulai dipertanyakan, kemudian mulai dikembangkan rasio PER yang mempertimbangkan pertumbuhan pendapatan atau yang dikenal sebagai price earnings ratio adjusted by growth (PEG). Rasio PEG adalah rasio yang membandingkan PER dengan pertumbuhan pendapatan. Perusahaan dengan nilai PEG rendah menunjukkan bahwa perusahaan tersebut memiliki risiko tinggi, sehingga sesuai dengan konsep high risk high return, investor berpotensi memperoleh pendapatan saham yang tinggi. Akan tetapi, rasio PEG masih belum mampu menunjukkan seberapa besar perbedaan risiko dua saham yang memiliki nilai PEG sama, sehingga mulai dikembangkan rasio PER yang mempertimbangkan pertumbuhan pendapatan dan risiko atau yang dikenal sebagai price earnings ratio adjusted by growth and risk (PERG).

Rasio PERG pertama kali diperkenalkan oleh Estrada (2005) dalam penelitiannya yang bertujuan untuk membandingkan kinerja portofolio saham yang dibentuk berdasarkan nilai masing-masing PER, PEG, dan PERG. Hasil perbandingan tersebut menunjukkan bahwa kinerja portofolio saham PERG lebih mendekati kenyataannya, sehingga mampu memprediksi pendapatan saham lebih baik dibanding PEG dan PER. Sareewiwatthana (2014) mengadaptasi penelitian Estrada (2005) dengan model yang sama persis, namun menunjukkan hasil berbeda yakni PER mampu memprediksi pendapatan saham lebih baik dibanding PEG dan PERG. Ghanbarian et. al (2015) kemudian berusaha membandingkan 
masing-masing pengaruh PER dan PERG terhadap pendapatan saham untuk melihat manakah rasio yang mampu menunjukkan model yang lebih baik dalam memprediksi pendapatan saham. Hasil regresi menunjukkan bahwa PERG merupakan model yang lebih baik dibandingkan PER.

Secara teori, PERG seharusnya bisa menjadi rasio yang lebih baik dalam memprediksi pendapatan saham karena mempertimbangkan pertumbuhan perusahaan dan risiko. Akan tetapi, perbedaan hasil penelitian juga menimbulkan pertanyaan mengenai kelayakan PERG sebagai prediktor pendapatan saham, sehingga penelitian ini dilakukan untuk meninjau kembali kelayakan PERG sebagai prediktor pendapatan saham.

\section{LANDASAN TEORI DAN PENGEMBANGAN HIPOTESIS}

\section{Pendapatan saham}

Pendapatan saham adalah tingkat pengembalian atau tingkat keuntungan yang diterima investor dari hasil investasi saham yang dilakukannya. Sumber pendapatan saham dapat berupa dividen dan pendapatan modal. Dividen adalah bagian laba bersih setelah pajak yang dibagikan perusahaan kepada pemegang saham. Pendapatan modal adalah pendapatan yang diperoleh dari selisih harga jual dengan harga beli saham. Selisih harga jual dengan harga beli yang bernilai positif disebut dengan capital gain, sedangkan selisih yang negatif disebut dengan capital loss. Pendapatan saham yang memperhitungkan capital gain dan dividen dapat dihitung dengan rumus sebagai berikut:

$R_{i, t}=\frac{P_{i, t}-P_{i, t-1}}{P_{i, t-1}}+\frac{D_{i, t}}{P_{i, t-1}}$

Keterangan:

$R_{i, t} \quad=$ pendapatan saham perusahaan i pada periode $\dagger$

$P_{i, t} \quad=$ harga pasar saham perusahaan i pada periode $\dagger$

$P_{i, t-1} \quad=$ harga pasar saham perusahaan i pada periode $\mathrm{t}-1$

$D_{i, t} \quad=$ dividen perusahaan i pada tahun $\dagger$

Bila pendapatan saham hanya memperhitungkan capital gain saja, maka besar kecilnya pendapatan saham dapat dihitung dengan rumus:

$R_{i, t}=\frac{P_{i, t}-P_{i, t-1}}{P_{i, t-1}}$

Keterangan:

$R_{i, t} \quad=$ pendapatan saham perusahaan i pada periode $\dagger$

$P_{i, t} \quad=$ harga pasar saham perusahaan i pada periode $\dagger$

$P_{i, t-1} \quad=$ harga pasar saham perusahaan i pada periode $t_{-1}$

\section{Price earnings ratio (PER)}

Rasio PER adalah rasio yang menunjukkan besarnya harga saham yang harus dibayar oleh investor untuk mendapatkan satu rupiah laba per lembar saham. Perhitungan PER 


\section{Made Sudana}

\section{Hilda Putri Maulidiyah}

digunakan untuk mengukur apakah sebuah saham dihargai terlalu tinggi atau rendah bila dibandingkan dengan laba per lembar sahamnya. Rasio PER dapat dihitungdengan rumus: $P E R_{i, t}=\frac{P_{i, t}}{E P S_{i, t}}$.

Keterangan:

$P E R_{i, t} \quad=$ price earnings ratio perusahaan i pada periode $\dagger$

$P_{i, t} \quad=$ harga pasar sahamperusahaan i pada periode $\dagger$

$E P S_{i, t} \quad=$ laba per lembar sahamperusahaan i pada periode $\dagger$

Selain PER, terdapat rasio pengembangan PERyang digunakan untuk menentukan hubungan antara harga saham dan pendapatan saham. Bila PER hanya mempertimbangkan harga saham dan pendapatan saham, PER yang dikembangkan jugamempertimbangkan faktor lain diluar harga saham dan pendapatan saham, seperti pertumbuhan jangka panjang (PEG) dan risiko (PERG).

\section{Price earning ratio adjusted by growth (PEG)}

Rasio PEG adalah rasio PER yang mempertimbangkan pertumbuhan jangka panjang (Sareewiwatthana, 2014). Rasio PEG bertujuan membandingkan PER dengan tingkat pertumbuhan yang diharapkan untuk mengidentifikasi apakah saham perusahaan undervalue atau overvalue. Besar kecilnya PEG dapat diukur dengan rumus:

$P E G_{i, t}=\frac{P E R_{i, t}}{\mathrm{~g}_{i, t}}$

Keterangan:

$P E G_{i, t} \quad=$ price earnings ratio to growth perusahaan i pada periode $\dagger$

$P E R_{i, t} \quad=$ price earnings ratio perusahaan i pada periode $\dagger$

$\mathrm{g}_{i, t} \quad=$ pertumbuhan (growth) EPSperusahaan i pada tahun $\dagger$

Semakin rendah nilai $P E G$, maka semakin tinggi laba per lembar saham yang diperoleh investor. Nilai PEG yang rendah menunjukkan bahwa investor memeroleh saham pada tingkat harga yang murah (undervalue). Ketika pertumbuhan perusahaan tinggi, maka harga saham akan meningkat dengan cepat di pasar, sehingga laba per lembar saham yang diperoleh investor juga akan meningkat. Besar kecilnya pertumbuhan dapat diukur dengan rumus:

$\mathrm{g}_{i, t}=\frac{E P S_{i, t}-E P S_{i, t-1}}{E P S_{i, t-1}}$

Keterangan :

$\mathrm{g}_{i, t} \quad=$ pertumbuhan perusahaan i pada tahun $\dagger$

$E P S_{i, t} \quad=$ laba per lembar saham perusahaan i pada tahun $\dagger$

$E P S_{i, t-1}=$ laba per lembar saham perusahaan i pada tahun $\mathrm{t}-1$ 
Price earnings ratio adjusted by growth and risk (PERG)

Rasio PERG adalah rasio PEG yang memperhitungkan risiko. Sejalan dengan Estrada (2005), Ghanbarian et al (2015: 284) menyatakan bahwa semakin rendah nilai PERG saham, semakin menguntungkan saham tersebut, karena kondisi ini menunjukkan bahwa saham tersebut undervalue, yang berarti investor memperoleh saham pada tingkat harga yang murah. Sebaliknya, saham dengan nilai PERG yang tinggi menunjukkan bahwa saham tersebut overvalue, yang berarti investor memperoleh saham pada tingkat harga yang mahal.Besar kecilnya PERG dapat diukur dengan rumus:

$$
\begin{aligned}
P E R G_{i, t} & =\frac{P E R_{i, t}}{\mathrm{~g}_{i, t}} \times \beta_{i,} \\
& =P E G_{i, t} \times \beta_{i,}
\end{aligned}
$$

Keterangan:

$P E R G_{i, t}=$ price earnings to growth adjusted by risk perusahaan i pada periode $\dagger$

$P E G_{i, t} \quad=$ price earnings ratio to growth perusahaan i pada periode $\dagger$

$\beta_{i, t} \quad=$ beta saham perusahaan i pada periode $\dagger$

Risiko yang digunakan dalam perhitungan PERG adalah risiko sistematis berupa beta saham dan diukur dengan meregresikan pendapatan saham perusahaan dengan pendapatan pasar saham menggunakan rumus:

$R_{i, t}=\alpha_{i, t}+\beta_{i, t} R M_{t}$

Keterangan:

$R_{i, t} \quad=$ pendapatan saham perusahaan i pada minggu $\dagger$

$\alpha_{i, t} \quad=$ konstanta regresi

$\beta_{i, t} \quad=$ beta saham perusahaan i pada minggu $\dagger$

$R M_{t} \quad=$ pendapatan pasar saham pada minggu $\dagger$

Pendapatan pasar saham merupakan pendapatan saham gabungan seluruh perusahaan yang terdaftar di bursa saham dan dihitung dengan rumus sebagai berikut.

$R M_{t}=\frac{I H S G_{t}-I H S G_{t-1}}{I H S G_{t-1}}$

Keterangan:

$R M_{t} \quad=$ pendapatan pasar saham pada minggu $\dagger$

$I H S G_{t} \quad=$ indeks harga saham gabungan pada minggu $\dagger$

$I H S G_{t-1}=$ indeks harga saham gabungan pada minggu t- 1

\section{Strategi pengambilan keputusan investasi saham dengan menggunakan PER}

Tinggi rendahnya PER perusahaan dapat dijadikan pertimbangan pengambilan keputusan investasi oleh investor. Pengambilan keputusan dengan menggunakan PER tergantung pada strategi yang digunakan. Terdapat dua strategi pengambilan keputusan yang didasarkan pada nilai PER, yaitu:

1. Growth strategy atau high strategy, merupakan strategi yang memilih saham-saham dengan nilai PER yang tinggi. Ketika kepercayaan investor terhadap prospek 


\section{Made Sudana \\ Hilda Putri Maulidiyah}

pertumbuhan perusahaan di masa depan baik, maka investor akan rela membayar lebih mahal sebab investor yakin bahwa perusahaan yang bertumbuh dengan baik akan mampu meningkatkan nilai perusahaan, sehingga saham-saham dengan nilai PER tinggi dapat dikategorikan sebagai saham yang bertumbuh (growth stock). Investor yang menganut strategi ini beranggapan bahwa saham dengan PER tinggi mampu memberikan pendapatan saham yang lebih tinggi dibandingkan dengan PER rendah, sehingga semakin tinggi PER, maka semakin tinggi pula pendapatan saham yang akan diperoleh dari investasi saham.

2. Value investing stategy atau low strategy, merupakan strategi yang memilih sahamsaham dengan nilai PER yang rendah. Saham dengan PER rendah merupakan saham yang dihargai lebih murah dari laba per lembar sahamnya. Investor yang membeli saham pada harga murah akan memperoleh capital gain yang tinggi ketika berhasil menjualnya pada tingkat harga yang lebih tinggi, sehingga saham dengan PER rendah disebut juga value stock. Investor yang menganut strategi ini beranggapan bahwa saham dengan PER rendah mampu memberikan pendapatan saham yang lebih tinggi, sehingga semakin rendah $P E R$, maka semakin tinggi pula pendapatan saham yang akan diperoleh dari investasi saham.

Investor di Indonesia lebih menyukai saham yang dihargai lebih murah, sehingga penggunaan low strategy lebih popular di kalangan investor saham. Ang dan Zhang (2011) menyatakan bahwa jenis strategi tersebut lebih mendominasi hampir seluruh pola investasi dari investor saham di seluruh dunia semenjak Warren Buffet, seorang investor saham yang menganut value investing strategy, menjadi orang terkaya sedunia dengan kekayaan hingga $\$ 62$ milyar dari investasi saham yang dilakukannya. Buffet merupakan investor saham yang berhasil memperoleh pendapatan saham hingga $21.1 \%$ dari investasi saham antara 1965-2007. Hal tersebut menunjukkan bahwa investasi senilai \$1000 di tahun 1965 yang dilakukan oleh Buffet akan menghasilkan pendapatan saham hingga \$4 juta pada 2007. Pada periode yang sama, pasar saham yang memuat 500 perusahaan terbaik di Amerika hanya mampu memberikan pendapatan saham sebesar $10.3 \%$.

\section{Pengaruh PER, PEG, dan PERG terhadap pendapatan saham}

Rasio PER, PEG, dan PERG digunakan untuk menentukan apakah saham yang dibeli mampu memberikan pendapatan saham yang sesuai dengan pertumbuhan, risiko, dan harga yang dibayarkan. Bila ada dua saham dengan nilai PER yang sama namun memiliki tingkat pertumbuhan yang berbeda, maka saham dengan pertumbuhan lebih tinggi akan lebih menguntungkan. Bila ada dua saham dengan nilai PEG yang sama namun memiliki risiko yang berbeda, maka saham dengan risiko terendah akan lebih menguntungkan. Dengan 
kata lain, saham yang terbaik adalah saham yang memiliki PERG terendah, sebab saham tersebut lebih murah yang ditandai dengan nilai PER yang rendah, memiliki tingkat pertumbuhan yang tinggi dengan risiko yang relatif lebih rendah (Estrada, 2005: 191).

Pendapatan saham yang tinggi dimiliki oleh saham-saham dengan nilai PER, PEG, dan PERG terendah atau dengan kata lain semakin rendah nilai rasio PER, PEG, dan PERG, maka semakin tinggi pendapatan saham. Meski demikian, nilai terendah yang dimaksudkan adalah nilai rasio yang masih lebih besar dari nol atau tidak negatif. Nilai rasio yang negatif menunjukkan bahwa perusahaan mengalami kerugian atau pendapatan perusahaan menurun dibandingkan dengan tahun sebelumnya.

\section{H1: PER berpengaruh negatif terhadap pendapatan saham \\ H2: PEG berpengaruh negatif terhadap pendapatan saham \\ H3: PERG berpengaruh negatif terhadap pendapatan saham}

\section{Pengaruh faktor lain terhadap pendapatan saham}

Penelitian-penelitian mengenai PER menunjukkan hasil yang berbeda-beda. Penelitian oleh Fun (2012) dan Omran (2009) menunjukkan bahwa PER baik highstrategy maupun lowstrategy tidak mempengaruhi pendapatan saham. Basu (1977) menemukan bahwa lowstrategy mampu memberikan pendapatan saham lebih tinggi dibandingkan highstrategy. Sebaliknya, Chen et. al (2015) menemukan bahwa highstrategy mampu memberikan pendapatan saham lebih tinggi dibandingkan lowstrategy.

Aras dan Yilmaz (2008) menyatakan bahwa PER tidak bisa dijadikan sebagai prediktor pendapatan saham karena menunjukkan hasil yang berbeda-beda pada penelitianpenelitian di seluruh dunia. Selanjutnya, penelitian Fun (2012) dan Chen et. al (2015) menunjukkan bahwa penggunaan harga saham di masa depan untuk menghitung PER jauh lebih baik dibandingkan dengan data harga saham historis, sehingga dapat dikatakan bahwa PER masih bisa menjadi prediktor pendapatan saham. Omran (2009: 47) menyatakan bahwa penelitian mengenai PER perlu memasukkan faktor-faktor lain yang juga dapat mempengaruhi PER, agar model yeng terbentuk dapat memprediksi pendapatan saham dengan lebih baik.

Pendapatan saham perusahaan dipengaruhi oleh faktor eksternal dan internal perusahaan. Faktor eksternal dapat tercermin pada harga pasar saham yang terbentuk akibat adanya penawaran dan permintaan di pasar serta risiko sistematis yang dihitung dengan menggunakan beta saham. Faktor internal perusahaan, dalam hal ini terkait dengan fungsi keuangan, yaitu keputusan investasi, pendanaan, dan dividen yang akan memengaruhi pendapatan yang diharapkan dan risikonya (Sudana, 2011: 8). Faktor-faktor internal tersebut 


\section{Made Sudana \\ Hilda Putri Maulidiyah}

meliputi ukuran perusahaan, rasio book to market (M/B), financial leverage, dan dividen payout ratio (DPR).

\section{Ukuran Perusahaan (SIZE)}

Ukuran perusahaan adalah besar kecilnya perusahaan yang dilihat dari total aset yang dimiliki oleh perusahaan. Besar kecilnya ukuran perusahaandiukur dengan rumus:

SIZE $_{i, t}=\ln$ Total Asset ${ }_{i, t}$

Keterangan:

$\operatorname{SIZE}_{i, t} \quad=$ ukuran perusahaan i pada tahun $\dagger$

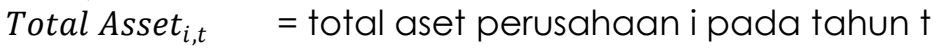

Teori asymmetric information yang menyatakan bahwa informasi yang diumumkan oleh perusahaan kecil dan kurang dikenal cenderung direspon secara berlebihan akibat keingintahuan investor yang tinggi. Perusahaan kecil jarang mempublikasikan informasi yang dimilikinya, sehingga informasi di pasar mengenai perusahaan kecil tersebut tidak diketahui oleh sebagian besar investor. Ketika sebuah informasi baik (good news) dipublikasikan, maka investor akan menganggap hal ini sebagai sinyal positif, sehingga informasi tersebut akan mampu menaikkan harga pasar saham perusahaan.

Perusahaan besar umumnya memiliki nama yang sudah banyak diketahui oleh masyarakat umum. Informasi yang dimiliki oleh perusahaan besar juga mudah diakses oleh investor karena sering dipublikasikan, sehingga setiap informasi yang dikeluarkan perusahaan akan direspon biasa saja oleh investor. Akibatnya, harga pasar saham perusahaan relatif tidak mengalami kenaikan dibandingkan dengan harga pasar saham perusahaan kecil, sehingga pendapatan saham berupa capital gain dari perusahaan besar cenderung lebih kecil dibandingkan perusahaan kecil, karena kurangnya minat investor.

\section{H4: SIZE berpengaruh negatif terhadap pendapatan saham}

\section{Market to Book Ratio(M/B)}

Rasio $M / B$ adalah perbandingan harga pasar saham perusahaan dengan nilai bukunya, yang mengukur penilaian pasar keuangan terhadap manajemen dan organisasi perusahaan sebagai going concern. Besar kecilnya rasio M/B dapat diukur dengan rumus:

$M / B_{i, t}=\frac{P_{i, t}}{B V_{i, t}}$

Keterangan:

$M / B_{i, t} \quad=$ market to book ratio perusahaan i pada tahun $\dagger$

$M P S_{i, t} \quad=$ harga saham penutupanperusahaan i pada tahun $\dagger$

$B V_{i, t} \quad=$ nilai buku per lembar sahamperusahaan i pada tahun $\dagger$

Besar kecilnya nilai buku per lembar saham dapat dihitung dengan rumus sebagai berikut: 
$B V_{i, t}=\frac{T E_{i, t}}{\mathrm{JSB}_{\mathrm{i}, \mathrm{t}}}$

Keterangan:

$B V_{i, t} \quad=$ nilai buku per lembar sahamperusahaan $\mathrm{i}$ pada tahun $\dagger$

$T E_{i, t} \quad=$ total ekuitas pemegang sahamperusahaan i pada tahun $\dagger$

$J S B_{i, t} \quad=$ Jumlah saham yang beredar perusahaan i pada tahun $\dagger$

Perusahaan yang dikelola dengan baik dan beroperasi secara efisien dapat memiliki nilai pasar yang lebih tinggi daripada nilai buku asetnya (Sudana, 2011: 24). Dengan demikian, semakin besar nilai pasar saham dibandingkan dengan nilai bukunya, berarti semakin baik pengelolaan yang dilakukan oleh manajemen perusahaan, sehingga hal ini bisa menjadi sinyal yang baik bagi investor dan akan meningkatkan harga saham perusahaan yang berujung pada peningkatan pendapatan saham

\section{H5: $M / B$ berpengaruh positif terhadap pendapatan saham}

\section{Leverage Keuangan (FLEV)}

Leverage keuangan adalah leverage yang timbul karena perusahaan dibelanjai dengan danaberupa utang yang menimbulkan beban tetap berupa bunga. Leverage keuangan diukur dengan menggunakan rumus:

$F L E V_{i, t}=\frac{L T D_{i, t}}{T E_{i, t}}$

Keterangan:

$F L E V_{i, t}=$ leverage keuangan perusahaan i pada tahun $\dagger$

$\operatorname{LTD}_{i, t} \quad=$ utang jangka panjang perusahaan i pada tahun $\dagger$

$T E_{i, t} \quad=$ total ekuitas perusahaan i pada tahun $\dagger$

Leverage kevangan digunakan dengan harapan dapat meningkatkan imbal hasil kepada para pemegang saham biasa, sehingga leverage jenis ini berhubungan langsung dengan pendapatan saham perusahaan. Leverage yang menguntungkan akan meningkatkan laba perusahaan sehingga laba per lembar saham meningkat. Peningkatan laba per lembar saham akan mendorong minat investor untuk memiliki saham tersebut. Ketika jumlah permintaan saham meningkat, namun jumlah saham yang beredar tetap, maka harga saham perusahaan meningkat. Peningkatan harga saham perusahaan pada akhirnya juga akan meningkatkan capital gain yang akan diperoleh investor.

Perusahaan menggunakan utang untuk mendanai investasi atau kegiatan-kegiatan operasional perusahaan. Ketika utang yang digunakan mampu meningkatkan laba bersih perusahaan, maka utang tersebut akan meningkatkan ekuitas pemegang saham. Bila sebaliknya, maka utang tersebut hanya akan menggerus ekuitas perusahaan. Ekuitas perusahaan yang semakin berkurang ketika perusahaan masih harus mendanai kegiatan 


\section{Made Sudana \\ Hilda Putri Maulidiyah}

operasional, akan membuat nilai aset perusahaan semakin menurun dan bila hal ini terus terjadi, maka perusahaan akan menghadapi kebangkrutan.

\section{H6: FLEV berpengaruh negatif terhadap pendapatan saham}

\section{Dividend Payout Ratio(DPR)}

Dividen payout ratio adalah rasio yang menunjukkan persentase laba bersih perusahaan yang diberikan kepada para pemegang saham secara tunai (Horne dan Wachowics, 2013: 206). Besar kecilnya DPR dapat dihitung dengan rumus sebagai berikut.

$D P R_{i, t}=\frac{\text { Total Dividen }_{i, t}}{E A T_{i, t}}$

Keterangan:

$D P R_{i, t} \quad=$ dividend payout ratio perusahaan i pada tahun $\dagger$

Total Dividen $_{i, t} \quad=$ total dividen perusahaan i pada tahun $\dagger$

$E A T_{i, t} \quad=$ laba setelah pajak perusahaan i pada tahun $\dagger$

Menurut teori bird in-the-hand, kebijakan dividen berpengaruh positif terhadap harga pasar saham. Artinya, jika dividen yang dibagikan perusahaan semakin besar, maka hal ini akan mendorong minat investor untuk memiliki saham tersebut. Ketika minat investor meningkat, maka jumlah permintaan saham tersebut juga akan meningkat, sedangkan jumlah saham yang beredar tetap. Berdasarkan hukum penawaran dan permintaan, ketika jumlah saham yang diminta meningkat padahal jumlah saham yang beredar tetap, maka harga pasar saham perusahaan tersebut meningkat. Sebaliknya, bila dividen yang dibagikan perusahaan semakin menurun, maka investor akan kehilangan minat untuk memiliki saham tersebut, sehingga harga pasar saham tersebut menurun. Hal ini dikarenakan pembagian dividen dapat mengurangi ketidakpastian yang dihadapi investor.

Pendapatan saham berupa dividen hanya didapatkan di akhir tahun operasional perusahaan yang kadangkala tidak dibagikan atau berupa laba ditahan. Sedangkan pendapatan saham berupa capital gain diperoleh ketika pemegang saham menjual saham yang dimilikinya. Kedua pendapatan tersebut membuat pemegang saham dihadapkan pada ketidakpastian dalam memperoleh pendapatan saham, sehingga pembayaran dividen menjadi sinyal yang positif bagi pemegang saham.

\section{H7: DPR berpengaruh positif terhadap pendapatan saham}

\section{MODEL ANALISIS}

Mengacu pada hipotesis yang diajukan, maka model analisis yang digunakan adalah tiga model analisis regresi sebagai berikut.

Model PER:

$R_{i, t}=\beta_{0}+\beta_{1} P E R_{i, t-1}+\beta_{2} S I Z E_{i, t-1}+\beta_{3} M / B_{i, t-1}+\beta_{4} F L E V_{i, t-1}+\beta_{5} D P R_{i, t-1}+\varepsilon_{i}$ 
Model PEG:

$R_{i, t}=\beta_{0}+\beta_{1} P E G_{i, t-1}+\beta_{2} S_{I Z E_{i, t-1}}+\beta_{3} M / B_{i, t-1}+\beta_{4} F L E V_{i, t-1}+\beta_{5} D P R_{i, t-1}+\varepsilon$

Model PERG:

$R_{i, t}=\beta_{0}+\beta_{1} P E R G_{i, t-1}+\beta_{2} \operatorname{SIZE}_{i, t-1}+\beta_{3} M / B_{i, t-1}+\beta_{4} F L E V_{i, t-1}+\beta_{5} D P R_{i, t-1}+\varepsilon_{i}$.

Keterangan:

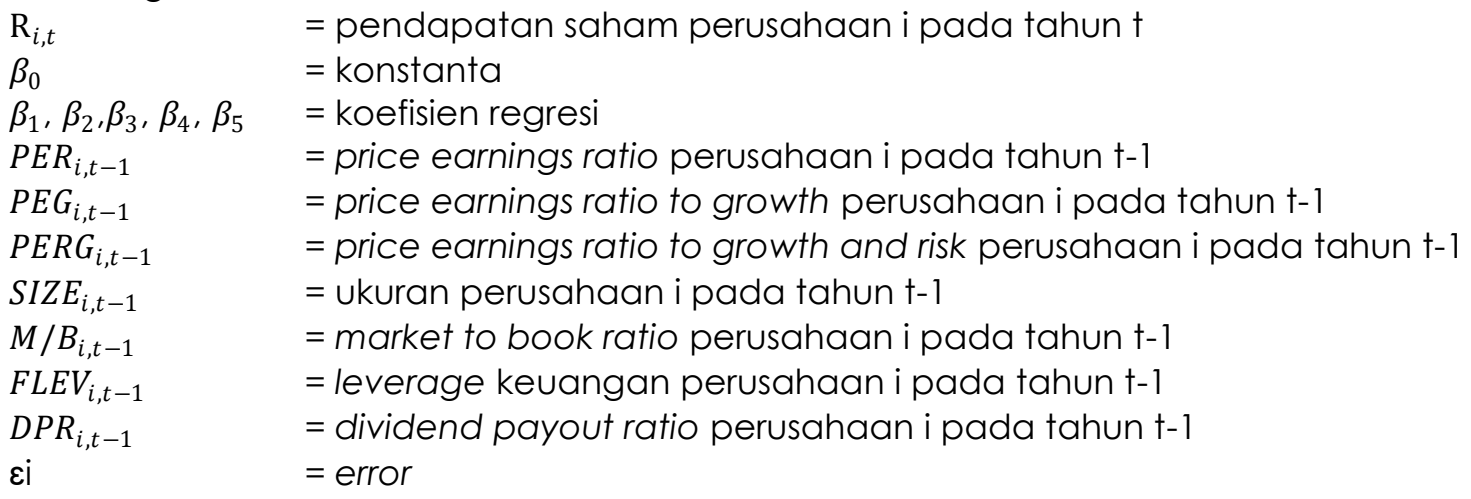

\section{METODE PENELITIAN}

\section{Populasi dan Sampel Penelitian}

Populasi dalam penelitian ini adalah perusahaan non-keuangan yang terdaftar di BEl sejak 2010-2016. Sampel dalam penelitian ini ditentukan dengan menggunakan metode purposive sampling sebagai berikut:

1. Perusahaan non keuangan yang sudah terdaftar di BEl sejak 2010-2016.

2. Perusahaan memiliki laporan keuangan tahunan yang telah diaudit secara berturutturut dari tahun 2010-2016.

3. Pendapatan per lembar saham (EPS) perusahaan yang terdapat pada laporan kevangan tidak bernilai negatif.

4. Total ekuitas perusahaan tidak bernilai negatif.

\section{Definisi Operasional Variabel}

Definisi operasional dalam penelitian ini dapat dikelompokkan sebagai berikut.

1. Pendapatan saham adalah pendapatan aktual saham berupa capital gain pada tahun t yang dihitung dengan menggunakan rumus (2).

2. Rasio PER merupakan perbandingan harga saham dengan laba per lembar saham perusahaan pada tahun t-1 yang dihitung dengan menggunakan rumus (3).

3. Rasio PEG adalah perbandingan antara PER dengan pertumbuhan EPSpada tahun ${ }^{t}-1$ yang dihitung dengan menggunakan rumus (4). 


\section{Made Sudana \\ Hilda Putri Maulidiyah}

4. Rasio PERG adalah rasio PEG yang memperhitungkan risiko sistematis berupa beta saham pada tahun $\mathrm{t}-1$, yang diukur dengan rumus (6).

5. Ukuran perusahaanadalah besar kecilnya perusahaan pada tahun $t-1$, yang diukur dengan rumus (9).

6. Rasio book to market value adalah rasio yang membandingkan nilai ekuitas per lembar saham dengan nilai pasar saham pada tahun $\mathrm{t}-1$ dan dihitung dengan rumus (10).

7. Leverage keuangan adalah perbandingan total utang jangka panjang dengan total ekuitas pada tahun $\mathrm{t}-1$, yang dihitung dengan rumus (12).

8. Dividend payout ratio adalah rasio laba bersih yang dibayarkan perusahaan secara tunai kepada para pemegang saham pada t-1, yangdapat dihitung menggunakan rumus (13).

\section{HASIL DAN PEMBAHASAN}

Berdasarkan hasil penelitian dapat diketahui nilai minimum, maksimum, dan nilai rata-rata masing-masing variabel dependen yaitu pendapatan saham, dan variabel independen yaitu PER, PEG, PERG, serta variabel kontrol yaitu SIZE, M/B, FLEV, dan DPR pada Tabel 1.

Pendapatan saham tertinggi sebesar 0,513, terendah sebesar -0,529, dan rata-rata pendapatan saham sebesar -0,037. Nilai PER tertinggi sebesar 2.760, terendah sebesar 0,347, dan rata-rata sebesar 50,957. Hal tersebut menunjukkan bahwa terdapat variasi nilai PER yang tinggi. Nilai PEG tertinggi sebesar 6.396,917, terendah sebesar $-7.842,857$, dan rata-rata sebesar -1,880. Hal tersebut menunjukkan bahwa terdapat variasi nilai PEG yang tinggi. Saham yang memiliki nilai PEG negatif menunjukkan bahwa perusahaan mengalami penurunan laba dibandingkan dengan tahun sebelumnya, sehingga nilai yang semakin negatif menunjukkan kondisi pertumbuhan perusahaan yang semakin buruk. Nilai PERG tertinggi sebesar 2.497.479, terendah sebesar -3.029.822, dan rata-rata sebesar $-0.822 \mathrm{Hal}$ ini menunjukkan bahwa terdapat variasi nilai PERG yang tinggi. Sama halnya dengan PEG negatif, saham yang memiliki nilai PERG negatif juga menunjukkan bahwa perusahaan mengalami penurunan laba per lembar saham dibandingkan dengan tahun sebelumnya. Dapat disimpulkan bahwa nilai PERG yang terbaik adalah yang terendah namun masih bernilai positif. Jika nilai PERG semakin negatif, maka saham tersebut menunjukkan kondisi laba perusahaan yang buruk.

Nilai ukuran perusahaan tertinggi sebesar 33,203, terendah sebesar 21,727, dan rata-rata sebesar 28,467. Market to book ratio menunjukkan kemampuan perusahaan dalam menumbuhkan kekayaan yang dimiliki oleh investor saham. Perusahaan yang baik akan 
mampu meningkatkan nilai modal yang dimilikinya melalui kegiatan operasional maupun investasi yang efisien, sehingga nilai pasar sahamnya dapat meningkat melebihi nilai bukunya. Rasio M/B tertinggi sebesar 556,026, terendah sebesar 0,037, dan rata-rata sebesar 6,787. Rasio FLEV tertinggi sebesar 12,129, terendah sebesar 0,000, dan rata-rata sebesar 0,410 , dengan standar deviasi sebesar 0,685. NilaiDPR tertinggi sebesar 63,212, terendah sebesar 0,000, dan rata-rata sebesar 0,389.

Tabel 1. Statistik Deskriptif Variabel Penelitian

\begin{tabular}{crrr}
\hline Variabel & Minimum & Maksimum & Rata-rata \\
\hline Pendapatan Saham & $-0,529$ & 0,513 & $-0,037$ \\
PER & 0,347 & 2,760 & 50,957 \\
PEG & $-7842,857$ & 6396,917 & $-1,88$ \\
PERG & $-3029,822$ & 2497,497 & 0,822 \\
SIZE & 0,037 & 556,026 & 6,787 \\
M/B & 21,727 & 33,203 & 28,467 \\
FLEV & 0 & 12,129 & 0,41 \\
DPR & 0 & 63,212 & 0,39 \\
\hline $\mathbf{N}=\mathbf{8 7 4}$ & & & \\
\hline
\end{tabular}

\section{Analisis Model dan Pengujian Hipotesis}

Berdasarkan hasil analisis pada Tabel 2 untuk ketiga model regresi, hanya variabel M/B yang berpengaruh positif terhadap pendapatan saham, sedangkan variabel PER, PEG, PERG, SIZE,FLEV, dan DPR berpengaruh negatif terhadap pendapatan saham. Hasil analisis juga menunjukkan bahwa hanya variabel M/B dan FLEV yang berpengaruh signifikan terhadap pendapatan saham, sedangkan variabel PER, PEG, PERG, SIZE, dan DPR tidak berpengaruh signifikan terhadap pendapatan saham. Dapat disimpulkan bahwa semakin tinggi rasio $\mathrm{M} / \mathrm{B}$ dan semakin rendah leverage keuangan perusahaan, maka semakin tinggi pendapatan yang diterima investor.

Tabel 2. Hasil Analisis Regresi Berganda Model PER, PEG, dan PERG

\begin{tabular}{|c|c|c|c|c|c|c|}
\hline \multirow[b]{2}{*}{ Variabel } & \multicolumn{2}{|c|}{ Model PER } & \multicolumn{2}{|c|}{ Model PEG } & \multicolumn{2}{|c|}{ Model PERG } \\
\hline & $\begin{array}{c}\text { Koefisien } \\
\text { Regresi }\end{array}$ & Sig. uji t & $\begin{array}{c}\text { Koefisien } \\
\text { Regresi }\end{array}$ & Sig. uji t & $\begin{array}{c}\text { Koefisien } \\
\text { Regresi }\end{array}$ & Sig. uji t \\
\hline Constant & 0,040 & 0,772 & 0,031 & 0,820 & 0,029 & 0,832 \\
\hline PER/PEG/PERG & $-4,840$ & 0,907 & $-1,064$ & 0,332 & $-4,921$ & 0,113 \\
\hline SIZE & $-0,002$ & 0,606 & $-0,002$ & 0,647 & $-0,002$ & 0,658 \\
\hline$M / B$ & 0,001 & $0,000 * *$ & 0,001 & $0,000^{* *}$ & 0,001 & $0,000^{* *}$ \\
\hline FLEV & $-0,023$ & $0,042 *$ & $-0,023$ & $0,043^{*}$ & $-0,023$ & $0,044^{*}$ \\
\hline DPR & $-0,004$ & 0,194 & $-0,004$ & 0,188 & $-0,004$ & 0,183 \\
\hline F-Statistic & \multicolumn{2}{|c|}{4,426} & \multicolumn{2}{|c|}{4,616} & \multicolumn{2}{|c|}{4,938} \\
\hline Sig-F & \multicolumn{2}{|c|}{0,001} & \multirow{2}{*}{\multicolumn{2}{|c|}{$\begin{array}{l}0,000 \\
0,026\end{array}$}} & \multirow{2}{*}{\multicolumn{2}{|c|}{0,000}} \\
\hline R-square & \multicolumn{2}{|c|}{0,025} & \multirow{2}{*}{\multicolumn{2}{|c|}{$\begin{array}{l}0,026 \\
0,020\end{array}$}} & & 0,028 \\
\hline Adj. R-square & \multicolumn{2}{|c|}{0,019} & & & \multicolumn{2}{|c|}{0,022} \\
\hline Durbin Watson & \multicolumn{2}{|c|}{2,073} & \multicolumn{2}{|c|}{$\begin{array}{l}0,020 \\
2,073\end{array}$} & \multicolumn{2}{|c|}{2,071} \\
\hline
\end{tabular}

*significat $(a)=5 \%$

**significat $(a)=1 \%$ 


\section{Made Sudana \\ Hilda Putri Maulidiyah}

Nilai $R$-Square sebesar 0,025 pada model PER, 0,026 pada model PEG, dan 0,028 pada model PERG. Hal tersebut menunjukkan bahwa variabel seluruh variabel penelitian mampu menjelaskan perubahan variabel pendapatan saham sebesar 2,5\% pada model PER, 2,6\% pada model PEG, dan 2,8\% pada model PERG, sedangkan sisanya dijelaskan oleh variabel lain yang tidak dimasukkan ke dalam model. Model PERG memiliki nilai R-Square tertinggi, sesuai dengan teori yang dikemukakan sebelumnya, sehingga dapat disimpulkan bahwa PERG merupakan prediktor pendapatan saham terbaik dibandingkan dengan PEG dan PER.

\section{Price Earnings Ratio (PER)}

Hasil analisis regresi menunjukkan bahwa PER memiliki pengaruh negatif terhadap variabel pendapatan saham, sesuai dengan hipotesis yang telah dikemukakan. Hal tersebut sejalan dengan teori low strategy yang menyatakan bahwa semakin rendah nilai PER suatu saham, maka semakin tinggi kemungkinan pendapatan saham yang akan diperoleh investor di masa mendatang. Nilai PER yang rendah menunjukkan bahwa saham dihargai pada tingkat harga yang lebih murah dibandingkan dengan nilai sebenarnya saham tersebut. Ketika pasar menyadari nilai sebenarnya suatu saham, maka harga saham tersebut akan meningkat, sehingga pendapatan saham berupa capital gain yang diterima investor juga akan meningkat.

Hasil penelitian ini sesuai dengan penelitian Fun (2010) yang menemukan bahwa investor di Indonesia lebih menyukai saham yang murah, sehingga prinsip low strategy yang memilih saham-saham dengan nilai PER positif terendah lebih sesuai digunakan sebagai bahan pertimbangan pengambilan keputusan investasi di Indonesia. Basu (1977), Rosenberg (1985), dan Chen et. al (2015) juga menemukan bahwa saham dengan nilai PER yang rendah akan menghasilkan pendapatan saham yang lebih tinggi, karena dalam jangka panjang harga saham tersebut akan meningkat hingga mencapai titik harga yang sesuai dengan nilai intrinsiknya atau bahkan lebih tinggi lagi.

\section{Price Earnings RatioAdjusted by Growth (PEG)}

Saham dengan nilai PER rendah akan memberikan tingkat pendapatan saham yang tinggi, tetapi jika tidak didukung dengan nilai pertumbuhan yang tinggi, maka harga sahamnya akan mengalami penurunan, sehingga pendapatansaham tersebut tidak akan sebesar pendapatan saham dengan nilai PER yang sama tetapi tingkat pertumbuhannya lebih tinggi. Oleh karena itu, rasio PEG digunakan untuk melihat apakah saham dengan nilai PER yang rendah sudah didukung dengan tingkat pertumbuhan yang tinggi. Sama halnya dengan $P E R$, saham yang memiliki pendapatan tertinggi dimiliki oleh saham yang memiliki 
nilai PEG positif terendah. Hal tersebut menunjukkan bahwa PEG memiliki pengaruh negatif terhadap pendapatan, sesuai dengan hipotesis penelitian.

Perusahaan yang bertumbuh dengan pesat menunjukkan bahwa setiap rupiah yang diinvestasikan oleh investor mampu dikelola secara efektif dan efisien, sehingga perusahaan mampu menghasilkan laba yang lebih tinggi dalam rangka meningkatkan kekayaan pemegang saham. Kondisi tersebut mendorong investor memilih saham-saham dengan potensi pertumbuhan yang baik. Meningkatnya minat investor akan menyebabkan peningkatan harga saham, sehingga perusahaan yang memiliki pertumbuhan tinggi cenderung memiliki pendapatan saham yang lebih tinggi dibandingkan dengan perusahaan yang tidak bertumbuh atau mengalami penurunan pertumbuhan. Hal tersebut sesuai dengan penelitian yang dilakukan oleh Estrada (2005) dan Sareewiwatthana (2014) yang menemukan bahwa kinerja portofolio dari saham-saham dengan nilai PEG rendah jauh lebih baik dibandingkan kinerja pasar. Hal tersebut menunjukkan bahwa portofolio yang dibentuk dari saham-saham dengan nilai PEG positif terendah akan mampu memberikan pendapatan saham yang tinggi.

\section{Price Earnings Ratio Adjusted by Growth and Risk (PERG)}

Saham bertumbuh yang dihargai murah belum bisa dikatakan sebagai saham yang terbaik, bila tidak diimbangi dengan risiko yang rendah. Investor tentu akan lebih menyukai saham lain yang berisiko lebih rendah pada tingkat pendapatan saham yang sama, sehingga harga saham tersebut meningkat dan potensi pendapatan saham yang akan diterima investor juga akan meningkat. Ketika membuat keputusan investasi untuk memperoleh pendapatan saham yang tinggi, investor akan memerhatikan risiko yang menyertai setiap keputusan yang dipilihnya, sehingga penggunaan PERG sebagairasio PER yang memperhitungkan pertumbuhan dan risiko perusahaan mulai diperhitungkan. Hasil analisis regresi menunjukkan bahwa PERG memiliki pengaruh negatif terhadap pendapatan saham, sesuai dengan hipotesis penelitian yang telah dikemukakan.

Penelitian mengenai PERG merupakan penelitian yang terbilang baru, sehingga jenis penelitian yang membahas tentang PERG masih jarang ditemukan. Berbeda dengan penelitian ini, hasil penelitian Ghanbarian (2015) menunjukkan pengaruh positif signifikan PERG terhadap pendapatan saham. Penentuan pengaruh PERG terhadap pendapatan saham tergantung pada jenis strategi PER yang diteliti. Sesuai dengan penjelasan pada landasan teori, terdapat dua strategi pengambilan keputusan berdasarkan nilai PER, yakni low dan highstrategy. 


\section{Made Sudana \\ Hilda Putri Maulidiyah}

Penelitian Ghanbarian mengambil sampel perusahaan di Turki yang mayoritas investornya menganut highstrategy, sedangkan investor di Indonesia menganut lowstrategy, sehingga hasil regresi yang diperoleh menunjukkan hasil yang berkebalikan. Penelitian yang menganut high strategy merupakan jenis penelitian yang fokus pada saham yang bertumbuh (growth stock), sedangkan low strategy fokus pada saham yang bernilai lebih rendah dari nilai intrinsiknya (value stock), sehingga membandingkan keduanya, sama dengan membandingkan dua hal yang berbeda. Penelitian ini fokus pada low strategy, sehingga hubungan negatif antara PERG dan pendapatan saham merupakan hasil yang lebih sesuai.

Penelitian yang dilakukan oleh Estrada (2005), menemukan bahwa kinerja portofolio saham yang disusun dari saham-saham dengan nilai PERG positif terendah akan menghasilkan kinerja yang melampaui kinerja pasar. Hal ini membuktikan bahwa memilih saham berdasarkan nilai PERG yang terendah merupakan strategi yang sebaiknya dilakukan investor untuk meningkatkan pendapatan saham. Pemilihan PERG dengan nilai terendah yang dilakukan oleh Estrada (2005) menunjukkan low strategy, sama dengan strategi yang banyak digunakan investor di Indonesia.

Meski demikian, hasil analisis ini tidak menunjukkan pengaruh yang signifikan, berarti PER, $P E G$, dan PERG tidak memiliki pengaruh terhadap pendapatan saham. Beberapa penelitian mengenai PER yang dikemukanan oleh Fun (2010) menemukan bahwa baik dalam jangka panjang maupun pendek, PER tidak mempengaruhi pendapatan saham secara signifikan. Hal tersebut menunjukkan bahwa meskipun dalam penelitian ini PERG dapat menjadi prediktor terbaik pendapatan saham dibandingkan PER dan PEG, akan tetapi prediksi tersebut tidak akan akurat sebab terdapat variabel lain diluar variabel penelitian yang mempengaruhi pendapatan saham secara signifikan.

\section{Ukuran Perusahaan (SIZE)}

Ukuran perusahaan menunjukkan besar kecilnya perusahaan yang dilihat dari total aset yang dimiliki oleh perusahaan. Hasil analisis regresi menunjukkan pengaruh negatif signifikan ukuran perusahaan terhadap pendapatan saham, sesuai dengan hipotesis. Perusahaanperusahaan besar biasanya sudah banyak dikenal dan senantiasa disorot oleh masyarakat luas, sehingga setiap informasi mengenai perusahaan tersebut mudah diakses oleh investor dari berbagai sumber. Sementara informasi pada perusahaan-perusahaan kecil cenderung sulit diperoleh, karena perusahaan tersebut jarang mempublikasikan informasi yang dimilikinya. Hal ini mengakibatkan informasi yang diumumkan oleh perusahaan kecil akan 


\section{Jurnal Manajemen Teori dan Terapan \\ Tahun 11. No. 2, Agustus 2018}

direspon secara berlebihan oleh investor, sehingga minat investor terhadap saham tersebut meningkat. Peningkatan harga saham akan meningkatkan pendapatan saham.

Hasil penelitian ini juga sesuai dengan penelitian Ghanbarian (2015) yang menunjukkan bahwa Ukuran perusahaan memiliki pengaruh negatif signifikan terhadap pendapatan

saham. Penelitian Pasaribu (2009) juga meneliti kinerja portofolio saham yang disusun berdasarkan dua kategori, yakni perusahaan besar dan perusahaan kecil. Terbukti bahwa kinerja portofolio saham yang disusun dari saham-saham perusahaan kecil mampu memberikan kinerja portofolio yang lebih tinggi dibandingkan dengan saham perusahaan besar.

\section{Market to Book Ratio (M/B)}

Hasil penelitian ini menunjukkan bahwa terdapat pengaruh positif signifikan $M / B$ terhadap pendapatan saham, sesuai dengan hipotesis. Rasio M/B adalah rasio antara harga pasar perlembar saham dengan nilai buku perlembar saham yang menunjukkan kemampuan perusahaan dalam meningkatkan kekayaan pemegang saham. Rasio ini juga menunjukkan seberapa besar pasar menilai kinerja perusahaan. Perusahaan yang memiliki kinerja baik mampu menggunakan dana investor dengan efektif dan efisien, sehingga akan menyebabkan peningkatan laba perusahaan. Perusahaan yang mampu menghasilkan keuntungan tentu akan lebih disukai oleh investor, sehingga permintaan terhadap saham perusahaan tersebut meningkat di pasaran. Peningkatan permintaan akan menyebabkan harga pasar saham perusahaan meningkat dan pada akhirnya akan meningkatkan pendapatan saham.

Hasil penelitian Stattman (1980) dan Rosenberg et. al (1985) menunjukkan bahwa M/B berpengaruh positif terhadap pendapatan saham. Hasil penelitian ini juga sesuai dengan hasil penelitian Er (2012) di Turki yang meneliti 23 variabel mikroekonomi dan 8 variabel makroekonomi yang mempengaruhi pendapatan saham. Hasil penelitian menunjukkan bahwa M/B masuk ke dalam salah satu variabel yang memiliki pengaruh positif signifikan dalam memprediksi pendapatan saham. Penelitian oleh Aras dan Yilmaz (2008) juga menunjukkan hasil yang sama, yakni M/B memiliki pengaruh yang positif signifikan dalam memprediksi pendapatan saham.

\section{Leverage Keuangan (FLEV)}

Leverage keuangan menunjukkan kemampuan perusahaan dalam mengelola utang untuk meningkatkan laba perusahaan. Hasil analisis menunjukkan bahwa terdapat pengaruh negatif signifikan FLEV terhadap pendapatan saham, sesuai dengan hipotesis yang 


\section{Made Sudana \\ Hilda Putri Maulidiyah}

dikemukakan sebelumnya. Hasil penelitian ini sesuai dengan penelitian Abdullah (2015) yang menunjukkan pengaruh negatif signifikan FLEV terhadap pendapatan saham.

Penggunaan utang yang dilakukan perusahaan dapat dijadikan informasi bagi investor mengenai kinerja keuangan perusahaan. Perusahaan yang memiliki utang akan menanggung biaya tetap berupa bunga utang, sehingga semakin tinggi utang, maka semakin tinggi pula biaya bunga yang ditanggung perusahaan. Bila utang yang ditanggung perusahaan semakin tinggi, sedangkan pendapatan perusahaan tetap, maka laba bersih perusahaan akan semakin rendah. Penurunan laba perusahaan akibat tingginya utang, akan dianggap sebagai penurunan kinerja kevangan perusahaan dan menyebabkan minat investor terhadap saham tersebut menurun. Menurunnya minat investor menyebabkan harga pasar saham tersebut rendah dan menurunkan pendapatan saham yang diterima investor.

\section{Dividend Payout Ratio (DPR)}

Dividen payout ratio merupakan salah satu jenis pendapatan saham yang diterima investor selain capital gain. Hasil analisis perusahaan non-keuangan di BEl menunjukkan bahwa terdapat pengaruh negatif tidak signifikan DPR terhadap pendapatan saham. Hasil penelitian ini tidak sesuai dengan hipotesis awal, namun sesuai dengan hasil penelitian Li (2015) yang menemukan bahwa terdapat pengaruh tidak signifikan DPR terhadap pendapatan saham.

Penelitian ini mendukung teori dividend irrelevance yang menyatakan bahwa kebijakan dividen perusahaan tidak mememngaruhi harga pasar saham perusahaan tersebut, sehingga juga tidak memengaruhi pendapatan saham. Sepanjang periode penelitian investor tidak menganggap pembayaran dividen yang dilakukan perusahaan sebagai sinyal pertumbuhan perusahaan, karena tidak semua perusahaan yang memiliki tingkat keuntungan yang tinggi akan langsung membayar dividen kepada investor. Perusahaan akan lebih mendahulukan pembayaran utang dan mendanai sejumlah investasi sebelum membayarkan dividen kepada investor. Hal ini sesuai dengan konsep residual dividend policy yang menyatakan bahwa perusahaan akan membayarkan dividen dari sisa laba (residual) yang dimilikinya, setelah digunakan untuk investasi. Pada kondisi tersebut, pembayaran dividen tidak akan direspon investor, sehingga tinggi rendahnya dividen tidak akan serta-merta menaikkan minat investor. 


\section{SIMPULAN DAN SARAN}

\section{Simpulan}

Berdasarkan pengolahan data dan pengujian hipotesis pada ketiga model regresi yang diajukan, diperoleh kesimpulan sebagai berikut:

1. Variabel PER, PEG, dan PERG memiliki pengaruh negatif tidak signifikan terhadap terhadap pendapatan saham, sesuai dengan konsep low strategy, sebab investor di Indonesia lebih suka membeli saham pada tingkat harga yang rendah untuk kemudian dijual kembali ketika harga saham tersebut meningkat dan lebih tinggi dibandingkan harga belinya.

2. Variabel SIZE pada ketiga model regresi memiliki pengaruh negatif tidak signifikan terhadap pendapatan saham, karena investor tidak menganggap ukuran perusahaan sebagai salah satu alasan utama dalam memilih saham yang hendak dibelinya.

3. Variabel M/B pada ketiga model regresi memiliki pengaruh positif signifikan terhadap pendapatan saham, sebab investor menyukai saham-saham yang memiliki nilai pasar lebih tinggi bila dibandingkan dengan nilai bukunya.

4. Variabel FLEV pada ketiga model regresi memiliki pengaruh negatif signifikan terhadap pendapatan saham, karena investor di Indonesia lebih menyukai perusahaan yang memiliki utang sedikit.

5. Variabel DPR pada ketiga model memiliki pengaruh negatif tidak signifikan terhadap pendapatan saham, sesuai dengan konsep dividend irrelevance dan residual dividend policy, karena perusahaan non-keuangan di Indonesia membayarkan dividen setelah mempertimbangkan peluang investasi.

6. ModelPERG merupakan model prediktor pendapatan saham terbaik dibandingkan dengan model PER dan PEG karena memiliki nilai R-square paling besar.

\section{Saran}

Berdasarkan kesimpulan yang telah dibuat, penulis memberikan saran sebagai berikut:

1. Bagi investor, diharapkan mempertimbangkan variabel $M / B$ dan FLEV ketika memperkirakan pendapatan saham perusahaan, namun tetap memperhatikan faktor lain yang mungkin mempengaruhi prediksi, seperti faktor makroekonomi dan mikroekonomi lainnya yang tidak dimasukkan dalam penelitian ini.

2. Bagi penelitian selanjutnya, dapat menggunakan betadownside sebagai ukuran risiko yang digunakan ketika menghitung PERG dan memakai rumus lain yang lebih sesuai ketika menghitung pertumbuhan perusahaan. 


\section{Made Sudana}

\section{Hilda Putri Maulidiyah}

\section{DAFTAR PUSTAKA}

Abdullah, Mohammad, et. al. 2015. The Impact Financial Leverage and Market Size on Stock Return on The Dhaka Stock Exchange: Evidence from Selected Stocks in The Manufacturing Sector. International Journal of Economics, Finance and Management Science, Vol. 3, Issue 1: 10-15.

Ang, Andrew dan Zhang, Xiaoyan. 2011. Price-Earnings Ratios: Growth and Discount Rates (Online), (http://www.columbia.edu/ aa610, diakses pada 10 November 2015).

Aras, Guler dan Yilmaz, Mustafa Kemal. 2008. Price Earnings Ratio, Dividend Yield, and Market-to-Book Ratio to Predict Return on Stock Market: Evidence from the Emerging Markets. Journal of Global Business and Technology, Vol.4, No.1 (spring): 18-30.

Basu, S. 1977. Investment Performance of Common Stocks in Relation to Their Price-Earnings Ratios: A Test of the Efficient Market Hypothesis. The Journal of Finance, Vol.32, No.3 (6): 663-682.

Chen, Li-Wen, et al. 2015. Revisting the Earnings-Price Effect: The Importance of Future Earnings. Finance Research Letters, 13 (3): 90-96.

Er, Sebnem. 2012. Factors Affecting Stock Return of Firms Quoted in ISE Market: A Dynamic Panel Data Approach. International Journal of Bussiness and Social Research, Vol.2, No.1 (-): 109-122.

Estrada, Javier. 2005. Adjusting P/E Ratios by Growth and Risk: the PERG Ratio. International Journal of Managerial Finance, Vol.1, No. 3 (-): 187-203.

Fun, Lim Pei dan Sautma Ronni Basana. 2012. Price Earnings Ratio and Stock Pendapatan Analysis (Evidence from Liquidity 45 Stocks Listed in Indonesia Stock Exchange). Jurnal Manajemen dan Kewirausahaan, Vol.14, No.1 (-): 7-12.

Ghanbarian, Babak, et al. 2015. A Comparison Can P/E and P/E Growth and Risk-Adjusted Basis in Explaining Stocks Pendapatans. Management and Administrative Sciences Review, Vol.4, Issue 2, (3): 284-296.

Li, George. 2015. Growth Options, Dividend Payout ratios, and Stock Returns. Management and Administrative Sciences Review, Vol.33, No.4 (-): 683-659.

. 2013. Analisis Laporan Keuangan, Proyeksi dan Valuasi Saham. Jakarta: Salemba Empat.

Omran, M. F. 2009. Price Earnings Multiples as Forecasters of Short Term Stock returns in Egypt. Journal of Economic and Administrative Sciences, Vol.25, No.1 (6): 47-66.

Pasaribu, Rowland B. Fernando. 2009. Model Fama dan French sebagai pembentukan Portofolio Saham di Indonesia. Jurnal Akuntansi dan Bisnis, Vol.9, No.1 (2): 1-12.

Rosenberg, B, et al. 1985. Persuasive Evidence of Market Inefficiency. Journal of Portofolio Management, 11, 9-17.

Sareewiwatthana, Paiboon. 2014. PE Growth and Risk: Evidences from Value Investing in Thailand. Technology and Investment, 5 (5): 116-124.

Stattman, Dennis. 1980. Book Values and Stock Returns. The Chicago MBA: A Journal of Selected Papers, 4, 25-45.

Sudana, I Made. 2011. Manajemen Keuangan Perusahaan Teori dan Praktik. Jakarta: Penerbit Erlangga. 